\title{
PRACTICAL REFLECTION ON THE WILL IN TERMSS OF EU REGULATION NO. 650/2012
}

\section{G.DUMITRACHE}

\section{Gabriela DUMITRACHE}

PhD student within "Alexandru Ioan Cuza" Police Academy in Bucharest, Romania - Law Mail address: AleeaPrivighetorilor, nr. 1-3, Sector 1, Bucharest, Romania E-mail: gabriela.dumitrache@gmail.com

\begin{abstract}
This article analyzes the will, in the light of the validity and form of conditions before the entry into force of the EU Regulation no. 650/2012 and after that date, and points out the problems of notarial practice faced by the Romanian public notary. The study presents the testamentary forms known in some European countries and the registers in which they are enrolled.
\end{abstract} Regulation

KEYWORDS: will, background conditions, formal conditions, Wills Register,

\section{INTRODUCTION}

The will is perhaps considered the most important act that a person concludes during his lifetime. It represents the legal pattern that can organize the material and economic aspects of the heirs, establish a new social order of the respective family nucleus, mark with the end of one's life the beginning of another, may attract - by the unfolding of previously unknown facts - or, on the contrary, his resentment ${ }^{l}$.

In solving an inheritance with extraneous elements, the Romanian public notary will have to determine the validity of the substance and form of a will. The question of the validity of wills is incident both at the moment of authentication of a will and in the case where a will is invoked in a succession procedure.

\section{THE TESTAMENT ISSUED PRIOR TO THE ENTRY INTO FORCE OF THE EU REGULATION NO.650 / 2012}

The present study aims to analyze the validity of the will in order to regulate them in the 2009 Romanian Civil Code and the European legislator's vision transposed into EU Regulation no. 650/2012 ${ }^{2}$.. Consequently, we will study the following assumptions:

- the testament drawn up between 01.10.2011 (date of entry into force of the Romanian Civil Code) and 17.08.2015 (date of implementation of the EU Regulation no. 650/2012);

- the particular aspects relating to the authentication of wills between 16.08.2012 (date of entry into force of EU Regulation No.650 / 2012 ${ }^{3}$ ) and 17.08.2015;

\footnotetext{
${ }^{1}$ A se vedeaDaniela Negrilă, Testamentul în noul Cod civil. Studii teoretice și practice, "Universul Juridic" Publishing House, București, 2013, fragment extras din prefaţa autoarei.

${ }^{2}$ Regulamentului UE nr. 650/2012 al Parlamentului European și al Consiliului privind competența, legea aplicabilă, recunoașterea și executarea hotărârilor judecătorești și acceptarea și executarea actelor autentice în materie de succesiuni şi privind crearea unui certificat european de moştenitor.
} 


\section{PRACTICAL REFLECTION ON THE WILL IN TERMSS OF EU REGULATION NO. $650 / 2012$}

- the particular aspects relating to the authentication of wills between 16.08.2012 (date of entry into force of EU Regulation No.650 / 2012) and 17.08.2015;

- the testament issued after the entry into force of EU Regulation No.650 / 2012.

The substantive conditions regarding the validity of the will are set by the law applicable to the inheritance, as well as the special inability to dispose of or to receive by will, according to art. 2636, para. g) Romanian Civil Code.

The other instances of inheritance, such as inheritance reserve, forced estate, reduction of excess liberties, and the donation are subject to the succession law.

When authenticating a will, the Romanian notary checks whether the will is valid from the point of view of the substantive conditions under the law applicable to the inheritance, but the conclusion of this test is in fact not judicious, because, until the death of the testator, the law applicable to his inheritance may be another, or the inheritance may be settled by another authority in another State which will be guided by its own rules of private international law. ${ }^{4}$.

However, we consider that, including the authentication of a will to be used in an international succession, the Romanian notary will verify the substantive conditions necessary for the validity of the will, namely the ability to test, the testator's consent, the lawful and moral cause, licit. ${ }^{5}$.

In all cases, the Romanian notary will authenticate a will in the form prescribed by the Romanian law, as a law of the place where the act was drafted, in accordance with the validity of the form of the will governed by Article 2635 of the Romanian Civil Code ${ }^{6}$.

With the entry into force of EU Regulation no. 650/2012 and 16.08.2012 respectively, notaries can authenticate wills that are considered valid in the light of the substantive conditions and formalities provided by Chapter III of EU Regulation No.650 / 2012. Just prior to the entry into force of EU Regulation no. 650/2012 in force and 17.08.2015 respectively, it provides $^{7}$ for the possibility of drawing up a will considered valid, subject to the death of the testator after 17.08.2015.

If at the debate of an inheritance with extraneous elements the notary is presented a testament drawn up between 16.08.2012 and 17.08.2015, the testator dying after 17.08.2015, the notary will appreciate the validity of the testament:

${ }^{3}$ Conform art. 84: "Prezentul regulament intră în vigoare în a douăzecea zi de la data publicării în Jurnalul Oficial al Uniunii Europene."

${ }^{4} \mathrm{~A}$ se vedeaIoana Olaru, Dreptul european al succesiunilor internaționale, Ghid practic, Editura Notarom, București, 2014, pag.102

${ }^{5}$ Art.1179 Cod civil român enumeră cele patru condiții de fond ale contractului, care în lumina art.1325 Cod civil: "Dacă prin lege nu se prevede altfel, dispoziţiile legale privitoare la contracte se aplică în mod corespunzător actelor unilaterale" pot fi adaptate la testament.

"', Intocmirea, modificarea sau revocarea testamentului sunt considerate valabile dacă actul respectă condiţiile de formă aplicabile, fie la data când a fost întocmit, modificat sau revocat, fie la data decesului testatorului, conform oricăreia dintre legile următoare:

a) legea naţională a testatorului;

b) legea reşedinţei obişnuite a acestuia;

c) legea locului unde actul a fost întocmit, modificat sau revocat;

d) legea situaţiei imobilului ce formează obiectul testamentului;

e) legea instanţei sau a organului care îndeplineşte procedura de transmitere a bunurilor moştenite.”

7 În art.83 alin.2: "În cazul în care defunctul a ales legea aplicabilă succesiunii sale înainte de 17 august 2015 , această alegere este valabilă dacă îndeplinește condițiile prevăzute în capitolul III sau dacă este valabilă în aplicarea normelor de drept internațional privat care erau în vigoare, la data efectuării alegerii, în statul în care defunctul își avea reședinţa obișnuită sau în oricare dintre statele a căror cetățenie o avea." 


\section{Gabriela Dumitrache}

- either in the light of the conditions set out in Chapter III of EU Regulation No.650 / 2012;

- either in accordance with the rules of private international law in force at the time the provision was made, in the State of the deceased's habitual residence, or in any of the States of which he or she was a national, or in the Member State in which the competent authority is situated succession.

As a matter of principle, for deceased deaths prior to 17.08.2015, which left a testament in the succession proceedings, its substantive validity will be analyzed by the Romanian notary in accordance with the law applicable to the succession and the validity of the form in the light of one of the listed laws by art.2635 Romanian Civil Code.

The multitude of practical difficulties is generated by wills drawn abroad.

Since 2002, the European Network of Testing Registers (RETT) ${ }^{8}$ has been established and can be used to identify a testament issued abroad or to verify whether it has been revoked or amended.

Also, on the website of the European Network of Testing Registers ${ }^{9}$ there is information on how to contact the National Registers and the wills found in EU Member States.

\section{THE WILL ACCORDING TO TO THE EU REGULATION NO. 650/2012}

In Chapter III of EU Regulation No.650 / 2012, the rules on wills are laid down in Articles 24, 26 and 27, which only apply if the testator dies after 17.08.2015. We note that once these conditions are met, these provisions apply both to the wills concluded after the date of entry into force of the Regulation (17.08.2015) and to those concluded between the date of entry into force of the Regulation (16.08.2012) and the date of its application (17.08 .2015). ${ }^{11}$.

From the norm that is drafted in Article 24 EU Regulation no. 650/2012, ${ }^{12}$ we infer that we will appreciate the substantive conditions validating a testament in accordance with the law that would have applied to the successor of the testator if he died on the day of the testament. This rule obliges the Romanian notary to carry out the following checks after 17.08.2015: - if he is asked to authenticate a will, he will proceed to investigate the admissibility and assimilation of the substantive testament conditions, first naming the law

\footnotetext{
${ }^{8}$ Rețeaua Europeană a Registrelor de Testamente a luat ființă în baza convenției de la Bâle din 16 mai 1972 referitoare la crearea unui sistem de înregistrare a testamentelor. Inițial interconectarea s-a realizat între fișierele testamentare belgiene și franceze.

${ }^{9} \mathrm{https}: / / \mathrm{www}$.arert.eu/Informations, $24 . \mathrm{html}$

${ }^{10}$ Regulamentul UE nr.650/2012 nu cuprinde o definiție a testamentului.

${ }^{11}$ Potrivit art.83 alin.3 Regulament: "O dispoziție pentru cauză de moarte întocmită înainte de 17 august 2015 este admisibilă și valabilă pe fond și în privința formei dacă îndeplinește condițiile prevăzute în capitolul III sau dacă este admisibilă și valabilă pe fond și în privința formei în aplicarea normelor de drept internațional privat care erau în vigoare în momentul întocmirii dispoziției, în statul în care defunctul își avea reședința obișnuită sau în oricare dintre statele a căror cetățenie o avea sau în statul membru în care se află autoritatea care se ocupă de succesiune"

12,'Dispoziții pentru cauză de moarte, altele decât pactele asupra unei succesiuni viitoare

(1) O dispoziție pentru cauză de moarte, alta decât un pact asupra unei succesiuni viitoare, este reglementată, în privința admisibilității sale şi a condițiilor de fond, de legea care, în temeiul prezentului regulament, ar fi fost aplicabilă succesiunii persoanei care a întocmit dispoziția, în cazul în care aceasta ar fỉ decedat în ziua întocmirii dispoziției.

(2) Fără a aduce atingere alineatului (1), o persoană poate alege ca lege care să îi reglementeze dispoziția pentru cauză de moarte, cu privire la admisibilitatea și condițiile de fond ale acesteia, legea pe care acea persoană ar fi putut să o aleagă în conformitate cu articolul 22, în condițiile stabilite de respectivul articol.

(3) Alineatul (1) se aplică, după caz, modificării sau revocării dispoziției pentru cauză de moarte, alta decât un pact asupra unei succesiuni viitoare. În eventualitatea alegerii legii în conformitate cu alineatul (2), modificarea sau revocarea este reglementată de legea aleasă."
} 


\section{PRACTICAL REFLECTION ON THE WILL IN TERMSS OF EU REGULATION NO. $650 / 2012$}

applicable to the succession as if the testator had died at the date of the testament. - if a testament in an international succession is invoked, the notary examines the admissibility and substantive validity of the will, in accordance with the law that would have applied to the succession, if the testator died at the date of the testament, and the law applicable to succession its timing.

This legislative novelty generates a double set of law applicable by the notary: ${ }^{13}$ : on the one hand it will determine the fictitious that would have been the law applicable to the succession at the date of the testament to verify its validity, on the other hand, will effectively determine the law applicable to the succession with a view to resolving it. In the final conclusion ${ }^{14}$ or in the certificate of heir, the results of these determinations shall be mentioned.

Article 26 EU Regulation No.650 / 2012 lists the substantive terms of the death penalty provisions: "1. For the purposes of Articles 24 and 25, the following shall refer to the substantive conditions:

(a) the capacity of the person making the provision for cause of death to draw up such a provision;

(b) special cases which prevent the person making the provision from dispensing for the benefit of certain persons or preventing a person from receiving inheritance from the person making the provision;

(c) the admissibility of representation in order to draw up a provision on the cause of death;

(d) the interpretation of the provision; or

(e) pain, violence, error, and any other matters relating to the consent or intent of the person making the provision.

" Article 26 paragraph 2 contains an important statement as to the testator's ability if the testator has the ability to test according to the applicable law in accordance with Articles 24 or 25 , the subsequent change in the applicable law does not affect his ability to modify or revoke such a provision. "As for the form, a written testament is valid if it meets the conditions laid down in one of the laws listed in Article 27 EU Regulation no. 650/2012: "Formal conditions of the death-related provisions drawn up in written form (1) A provision for a cause of death in written form fulfills the formal requirements if the form complies with the law:

(a) the State in which the provision on, or the conclusion of, the succession pact was concluded;

(b) the State of which the testator possesses the nationality or at least one of the persons whose succession is covered by a pact on a future succession either at the time of the provision or the conclusion of the covenant or at the time of death;

(c) the State of residence of the testator or at least one of the persons whose succession is covered by a pact on a future succession either at the time of the provision or the conclusion of the covenant or at the time of death;

\footnotetext{
${ }^{13}$ A se vedea Ioana Olaru, op.cit., pag. 107

${ }^{14}$ Încheierea finală reprezintă actul care marchează finalizarea procedurii succesorale. Ea desemnează momentul în care notarul procedează la "judecarea în fond" a cauzei succesorale.
} 


\section{Gabriela Dumitrache}

(d) the State of the habitual residence of the testator or at least one of the persons whose succession is covered by a pact on a future succession either at the time of the provision or the conclusion of the covenant or at the time of death; or

(e) in the case of immovable property, the State in which they are situated. Determining whether the testator or persons whose succession is covered by the pact on a future succession domiciled in a particular State is governed by the law of that State.

2. Paragraph 1 shall also apply to the death penalty provisions which amend or revoke a previous provision. The change or revocation fulfills the formal requirements if it complies with any of the laws under which, under paragraph 1, the provision for the cause of death which was amended or revoked was valid.

3. For the purposes of this Article, any provision of law limiting the permissible forms of death sentence by reference to the testator's age, nationality or other personal circumstances or persons whose succession is covered by a pact on a future successions belong to form matters. The same holds true for the qualifications that the witnesses need to have in order to validate a disposition for the cause of death. "

From a practical point of view, the notary in front of whom a will in an international succession is invoked, will enforce one of the laws provided by art. 27 Regulation, the law provided for in Article 24 being incidents.

For an example of implementing the provisions of EU Regulation no. 650/2012 evokes the following case: A Romanian citizen residing in Cluj, leaves a will on 03.08.2013, and on December 15, 2017 dies, having his habitual residence in Paris. What is the law on which to determine the special inability to receive by will, French law or Romanian law?

We note that according to art. 24 paragraph 1 in conjunction with art. 26 lit. b) of the EU Regulation no. 650/2012, it is the Romanian law that will determine these issues, being the law that would apply if the deceased died at the date of the will, not the French law, which is really applicable to the succession debate.

\section{FORMS OF WILL KNOWN IN SOME EUROPEAN STATES}

Forms of will known in some European states National wills registers provide information on the existence, revocation or modification of a will and can be consulted directly through the A.R.E.R.T. It is advisable to obtain a certificate provided by the Register of wills in the state of nationality or residence of the deceased when solving an international succession. Knowledge of the testamentary forms used in some European countries is of particular importance, especially since EU Regulation 650/2012 allows the signatory Member States of the Hague Convention of 5 October $1961^{15}$ on Conflict of Formal Laws of Testamentary Provisions (according to art. .75 paragraph1 of the Regulation) to apply these rules instead of Article 27 of the Regulation.

We note the view of the European legislator in favor of the testamenti ${ }^{16}$, namely to give the widest possible possibility that the will is formally valid in order to ensure legal certainty for people who want early succession planning. Paragraph 52 of the Preamble to the Regulation reveals that the alternative enumeration of the laws applicable to the form of the

\footnotetext{
${ }^{15} \mathrm{Pe}$ site-ul Conferinței de la Haga privind dreptul internațional privat (www.hcch.net) este prezentată lista statelor membre ale acestei convenții, convenție la care România nu este parte.

${ }^{16}$ Pentru detalii a se vedea I.-L. Vlad, Succesiuniinternaționale, Regulamentul nr.650/2012. Tratate internaționale în domeniu, "Universul Juridic” Publishing House, București, 2016, pag.103
} 
will conforms to the provisions of the Hague Convention of 5 October 1961 on Conflict of Laws Concerning the Form of Testamentary Provisions.

3.1 In France ${ }^{17}$, , the legislator allows the testator to express his last will through four categories of wills:

- handwriting wills, for which the following conditions must be met: be written entirely by the testator's hand, dated and signed by him;

- the authentic will to be considered valid must be drawn up before two notaries or a notary assisted by two witnesses;

- the mystical will, which is validly drafted under the following conditions: to be typed or handwritten by the testator or by another person, signed by the testator and presented closed and sealed before a notary and in the presence of two witnesses;

- the international will, the validity of which must be presented by the testator before a notary and two witnesses, be signed by them and then attached to a certificate drawn up by the notary, which will ensure that it is kept. ${ }^{18}$.

For opposing third party effects, French law requires that any will be recorded in an electronic database.

In France, there is the Central File of Testamentary Provisions, in which notaries proceed to the registration of wills and to query the database electronically. A will can only be signed by French notaries, consuls and ambassadors. We note that the French legislator is particularly concerned with the registration of the Holograph testament.

Any person who can prove his status as heir or legatee can consult the Central File of the Testamentary Provisions provided that the death certificate of the person whose will is sought is presented.

3.2 In Italy ${ }^{19}$, legislation recognizes the following forms of wills: - the authentic will, drawn up by the notary public - handwriting wills for which validity is required to be written, dated and signed by the testator's hand - the mystical will which is written by the testator's hand or a third person or typed and signed by the testator and involves the procedure of inserting it into a sealed envelope which is handed over to the notary in the presence of witnesses - the international will, which, in order to be valid, must be signed by the testator in the presence of two witnesses and a notary public. Two registers are regulated in Italy: a testamentary register under the administration of the Ministry of Justice and a succession register, which is administered by the Italian courts. In these registers the wills are registered and can be searched electronically. The inclusion of mortis causa provisions in the register is not mandatory, but the importance of registration can not be denied, as it facilitates discovery

\footnotetext{
${ }^{17}$ Succesiunile - Franța, https://e-justice.europa.eu/content_succession-166-FR-ro.do?clang=ro

Franța a semnat Convenția de la Bâle din 16 mai 1972, referitoare la crearea unui sistem deînregistrare a testamentelor și a ratificat-o la data de 20 septembrie 1974. De asemenea, a semnat Convenţia de la Haga din 5 octombrie 1961 privind conflictele de legi în materie de formă a dispozițiilor testamentare, ratificată la data de 20 septembrie 1967 "sub rezerva pentru Franța de a nu recunoaşte, în baza art.10 din Convenţie, dispoziţiile testamentare făcute în formă orală în afara cazurilor extraordinare de către unul dintre resortisanții săi care nu are o altă naţionalitate”. Franța a semnat Convenția de la Washington din 26 octombrie 1973 privind legea uniformă cu privire la forma testamentului internaţional și a ratificat-o la 1 iunie 1994.

${ }^{18}$ A se vedea Convenția de la Washington din 26.10.1973 privind legea uniformă asupra formei testamentului internațional

${ }^{19}$ Succesiunile - Italia, https://e-justice.europa.eu/content_succession-166-it-ro.do
} 


\section{Gabriela Dumitrache}

of the will. It is the public notary who records the wills in the electronic records and the task of preserving them regardless of the testamentary form used by the testator.

3.3 In Germany, ${ }^{20}$, a person can express his or her mortis causa by choosing one of the three forms of writings established by the $\operatorname{law}^{21}$ : authentic will ${ }^{22}$, handwritten testament or successor contract.

The authentic testament and succession contracts are drawn up by a notary ${ }^{23}$.

The jurisdiction to resolve a succession belongs to the judge under German law, and since January 1, 2012, a Central Register of Tests administered by the Federal Chamber of Notaries ${ }^{24}$ Notaries has been in operation in Germany, having as object the fulfillment of the advertising formalities imposed on mortis causa provisions.

Authentic wills and succession contracts must be filed with the local court. The notary who instructs an authentic testament has the obligation to fulfill the formalities of being submitted to the tribunal. Moreover, the authentic will is subject to registration in the wills register. Succession contracts may be filed with the local court or a notary and may form the subject matter of the entry in the Central Testing Registry. The handwriting test handwritten with the local court will be entered in the Central Testing Registry by the court. A testament made in Germany can be identified in the Central Testament Registry, with the exception of the testament handwriting which has not been deposited with the local court. The wills register can be interrogated only by notaries and judges.

\section{CONCLUSIONS}

When solving an international succession, the Romanian public notary investigates the validity and formality of the will in the light of the Romanian Civil Code or the EU Regulation no. 650/2012. The notary also obtains a certificate provided by the Register of wills in the state of nationality or residence of the deceased. The multitude of practical difficulties is generated by the wills drawn abroad, which require the notary to know the testamentary forms used in the European states. We retain the European legislator's view in favor of testaments, namely to allow the widest possible testament to be formally valid in order to ensure legal certainty for those who want early succession planning.

\section{BIBLIOGRAPHY}

I.-L. Vlad, Succesiuni internaționale, Regulamentul nr.650/2012. Tratate internaţionale în domeniu, "Universul Juridic" Publishing House, București, 2016

Ioana Olaru, Dreptul european al succesiunilor internaționale, Ghid practic, Notarom Publishing House, București, 2014

Daniela Negrilă, Testamentul în noul Cod civil. Studii teoretice și practice, "Universul Juridic" Publishing House, București, 2013

Codul civil român

\footnotetext{
${ }^{20}$ Germania este semnatară a Convenției de la Bâle din 16 mai 1972, referitoare la crearea unui sistem de înregistrare a testamentelor, dar aceasta nu a fost ratificată. Germania a semnat Convenția de la Haga din 5 octombrie 1961 privind conflictele de legi în materie de formă a dispozițiilor testamentare, ratificată la data de 20 noiembrie 1965. Germania nu a semnat Convenţia de la Washington din 26 octombrie 1973 privind legea uniformă cu privire la forma testamentului internaţional.

${ }^{21}$ Succesiunile - Germania, https://e-justice.europa.eu/content_succession-166-de-ro.do

${ }^{22}$ Denumit și "testament public"

${ }^{23}$ A se vedea Ioana Olaru, op.cit., pag. 111

24 "Bundesnotarkammer"
} 
Regulamentului UE nr. 650/2012 al Parlamentului European și al Consiliului privind competența, legea aplicabilă, recunoașterea și executarea hotărârilor judecătorești și acceptarea și executarea actelor autentice în materie de succesiuni și privind crearea unui certificat european de moștenitor

Convenţia de la Washington din 26.10.1973 privind legea uniformă asupra formei testamentului internațional

Succesiunile - Franța, https://e-justice.europa.eu/content_succession-166-FR-ro.do?clang=ro

Succesiunile - Germania, https://e-justice.europa.eu/content_succession-166-de-ro.do

Succesiunile - Italia, https://e-justice.europa.eu/content_succession-166-it-ro.do 